\title{
FOLIC ACID SUPPLEMENTATION IN PREGNANCY AND PREVENTION OF FETAL NEURAL TUBE DEFECTS
}

\author{
PRZYJMOWANIE KWASU FOLIOWEGO PRZEZ KOBIETY CIĘŻARNE \\ W PROFILAKTYCE WAD CEWY NERWOWEJ PŁODU
}

\author{
National Institute of Public Health - National Institute of Hygiene, \\ Department of Nutrition and Nutritional Value of Food \\ Narodowy Instytut Zdrowia Publicznego-Państwowy Zakład Higieny \\ Zakład Żywienia i Wartości Odżywczej Żywności
}

\begin{abstract}
INTRODUCTION: Folic acid deficiency in very early pregnancy significantly increases the risk for neural tube defects in the developing fetus. Due to very high demands for folic acid in pregnancy, adequate supply is not possible without dietary supplements.

AIM OF THE STUDY. Evaluation of the frequency and adequacy of folic acid supplementation before and during pregnancy among women from the Warsaw region of Poland.

MATERIAL AND METHODS. The study was conducted among 100 pregnant women using direct interviewing. Chi-square test was used to analyze the relationship between selected parameters and folic acid supplementation.

RESULTS. Folic acid before pregnancy was supplemented by $42 \%$ of the respondents. In pregnancy, the number almost doubled (83\%), but most women did not start the supplementation until 5-6 weeks of gestation. Before pregnancy, almost all subjects used single folic acid preparations, whereas during pregnancy they used vitaminmineral preparations for expectant women.

CONCLUSIONS. The realization of the Primary Prevention Program of Neural Tube Defects leaves much to be desired. Over half of the women do not supplement folic acid before conception, and the supply in pregnancy is initiated too late to meet the assumptions of the prevention program.
\end{abstract}

Key words: folic acid, pregnancy, neural tube, supplementation

\section{STRESZCZENIE}

WSTĘP: Niedobory kwasu foliowego w bardzo wczesnej ciąży zwiększają ryzyko wad cewy nerwowej płodu. Zapotrzebowanie kobiet ciężarnych na ten składnik jest na tyle duże, że bez suplementacji diety nie jest możliwa prawidłowa podaż.

CEL BADANIA. Ocena częstości i prawidłowości stosowania preparatów kwasu foliowego przed zajściem w ciążę oraz w okresie ciąży, przez kobiety z regionu warszawskiego.

MATERIAŁ I METODY. Badanie przeprowadzono wśród 100 kobiet ciężarnych, metodą bezpośredniego wywiadu z pacjentką. Związek wybranych cech ze stosowaniem kwasu foliowego analizowano przy pomocy testu chi2.

WYNIKI. Kwas foliowy przed zajściem w ciążę przyjmowało $42 \%$ badanych pacjentek. W okresie ciąży odsetek ten był dwukrotnie wyższy (83\%), ale większość kobiet rozpoczęła suplementację dopiero od 5-6 tygodnia ciąży. Przed zajściem w ciążę niemal wszystkie pacjentki zażywały pojedyncze preparaty kwasu foliowego, natomiast w okresie ciąży składnik ten przyjmowany był w postaci preparatów witaminowo-mineralnych, przeznaczonych dla kobiet ciężarnych.

WNIOSKI. Realizacja Programu Profilaktyki Pierwotnej Wad Cewy Nerwowej nie jest zadowalająca. Ponad połowa kobiet nie zażywa kwasu foliowego w okresie przedkoncepcyjnym, a po zajściu w ciążę podaż preparatu jest na tyle późna, że nie spełnia założeń profilaktyki.

Słowa kluczowe: kwas foliowy, ciąza, cewa nerwowa, suplementacja 


\section{INTRODUCTION}

Folic acid is the synthetic form of folates, a water-soluble B vitamin. Folates are important for a range of functions in the body. They participate in numerous one-carbon transfer reactions, including the methylation of DNA, and remethylation of homocysteine to the methionine. Folates are required for the normal production of red blood cells, and the synthesis of phospholipids and proteins. Insufficient supply of dietary folates can lead to folates deficiency in the body and can result in several health problems, including macrocytic anemia, cardiovascular disease, cancers, and birth defects $(1,2)$.

The relationship between folic acid intake and the development of the central nervous system in the fetus emphasizes the important role of folate during pregnancy $(3,4)$. The first studies on the effects of folic acid on the neural tube function date back to the 1960s (5), but it was not until the 90s that significant progress in the research was made. One of the first randomized trials, published in 1991 in the Lancet, demonstrated that daily supplementation of $4 \mathrm{mg}$ of folic acid among women with history of neural tube defects (NTDs) in previous pregnancy decreased the risk for that complication in the next pregnancy by $72 \%$. These authors stated that, at that point, it remained inconclusive whether all pregnant women should routinely take folic acid in pregnancy (5). Another randomized study by a Hungarian team proved a beneficial effect of taking $800 \mu \mathrm{g}$ of folic acid by women without elevated risk for NTDs (6), whereas a Chinese team claimed that supplementation with the dose of $400 \mu \mathrm{g} / \mathrm{day}$ in those women would suffice (7). Until today, the randomized trials have provided enough evidence to conclude that folic acid supplementation before conception decreases the risk for NTDs in the fetus by $69 \%$ (8).

The most common neural tube defects are anencephaly and spina bifida. Although spina bifida has a lower case fatality rate than other neural tube defects (approximately $7 \%$, compared with $100 \%$ for anencephaly), it can result in severe life-long morbidity $(9,10)$.

Already in 1992, the USA introduced guidelines for reproductive-age women to supplement folic acid in the dose of $400 \mu \mathrm{g} / \mathrm{day}$ (11). In Poland, the Primary Prevention Program of Neural Tube Defects was launched in 1998 and it continues to promote diet with high content of folate and daily supplementation of folic acid in the dose of $400 \mu \mathrm{g} /$ day by all women who might get pregnant. Folic acid supplementation should be continued at least through the first 12 weeks of gestation (12). The need to supplement folic acid already during the pre-conception period is associated with the fact that NTDs, which result from defective

\section{WSTEP}

Kwas foliowy jest syntetyczną formą folianów, należących do witamin $\mathrm{z}$ grupy B. Foliany pełnią w organizmie człowieka wiele kluczowych funkcji. Jako nośniki jednostek jednowęglowych uczestniczą w metylacji DNA i remetylacji homocysteiny do metioniny. Są niezbędne w procesie wytwarzania czerwonych krwinek oraz biora udział w syntezie białek i fosfolipidow. Niedobór folianów w diecie prowadzi do deficytów w organizmie, skutkiem czego może być niedokrwistość makrocytarna, choroby sercowo-naczyniowe, nowotwory, a także wady wrodzone płodu $(1,2)$.

Związek pomiędzy spożyciem kwasu foliowego przez kobiety ciężarne a rozwojem centralnego układu nerwowego płodu świadczy o ogromnym znaczeniu tego składnika w czasie ciąży $(3,4)$. Początek badań nad wpływem kwasu foliowego na czynność cewy nerwowej sięga lat sześćdziesiątych ubiegłego wieku (5), jednak poważny rozwój wiedzy na ten temat przyniosły dopiero lata 90 . Jedno z pierwszych randomizowanych, ogólnoświatowych badań, opublikowane w $1991 \mathrm{r}$. w renomowanym czasopiśmie The Lancet wykazało, że u kobiet ciężarnych, które w poprzedniej ciąży urodziły potomstwo $\mathrm{z}$ wadą cewy nerwowej, przyjmowanie $4 \mathrm{mg}$ kwasu foliowego dziennie, przed zajściem w kolejną ciążę zmniejszyło ryzyko tego powikłania o $72 \%$ (5). Autorzy publikacji wskazali wówczas, że na tym etapie wiedzy nie jest pewne, czy wszystkie kobiety ciężarne rutynowo powinny zażywać kwas foliowy. W kolejnym randomizowanym badaniu węgierskim, wśród kobiet nieobarczonych podwyższonym ryzykiem wad cewy nerwowej pło$\mathrm{du}$ udowodniono korzystny efekt stosowania $800 \mu \mathrm{g}$ kwasu foliowego (6), natomiast badanie chińskie wykazało, że w grupie takich kobiet wystarczająca jest suplementacja dawką $400 \mu \mathrm{g} / \mathrm{dzien}$ (7). W świetle analizy dotychczas przeprowadzonych badań randomizowanych przyjmowanie kwasu foliowego przed poczęciem dziecka zmniejsza ryzyko wad cewy nerwowej płodu o $69 \%$ (8).

Najczęściej występującymi wadami cewy nerwowej jest bezmózgowie i rozszczep kręgosłupa. Umieralność z powodu rozszczepu kręgosłupa jest znacznie mniejsza, niż w przypadku innych wad cewy nerwowej (około $7 \%$, w porównaniu z 100\% w przypadku bezmózgowia), ale takie dzieci mają poważne, dożywotnie problemy zdrowotne $(9,10)$.

$\mathrm{Na}$ gruncie postępującej wiedzy już w 1992 r. w USA wprowadzono zalecenia, aby kobiety w wie$\mathrm{ku}$ rozrodczym stosowały preparat kwasu foliowego w dawce $400 \mu \mathrm{g}$ dziennie (11). W Polsce ogólnokrajowy Program Profilaktyki Pierwotnej Wad Cewy Nerwowej funkcjonuje od 1998 r. i polega na propa- 
closure of the neural tube, may occur as early as at 3 or 4 weeks of gestation, typically before the woman finds out about the pregnancy. Supplementation initiated after the pregnancy has been confirmed by a gynecologist is usually not timely enough to benefit the developing fetus $(9,13)$. The national Primary Prevention Program of Neural Tube Defects includes all reproductive-age women in Poland as $95 \%$ of the neural tube defects occur for the first time $(5,6)$.

The opinions of the experts about the optimal time to start folic acid supplementation change as a result of the new research findings. Originally, folic acid supplementation was recommended at least 4 weeks before conception (12), then 6 weeks since the 2014 Polish Society of Gynecologists and Obstetricians Guidelines (14), followed by at least 12 weeks according to the new guidelines (2017) of this Society (15).

\section{AIM OF THE STUDY}

The aim of the study was to evaluate the frequency and adequacy of folic acid supplementation before and during pregnancy among women from the Warsaw region of Poland.

\section{MATERIAL AND METHODS}

The study was conducted among 100 pregnant women, who delivered at the Department of Obstetrics, Gynecology and Oncology, Medical University of Warsaw, in 2014-2015. Direct interviewing method was used to collect the data on folic acid supplementation and the demographics. The interviews were conducted by the same dietitian. Patient characteristics are presented in Table 1.

The chi-square test was used to analyze the association between folic acid supplementation and certain parameters (maternal age, education, place of inhabitance, parity, smoking in pregnancy). The p-value of $<0.05$ was considered as statistically significant. Stata v. 14.1 was used for statistical analysis.

Table 1. Patient characteristics

Tabela 1. Charakterystyka pacjentek

\begin{tabular}{|l|c|}
\hline Number of women & 100 \\
\hline Age (years), mean \pm SD & $30 \pm 4.4$ \\
\hline Education, (\%) & 66 \\
higher & 34 \\
other & \\
\hline Place of residence, (\%) & 58 \\
Warsaw city & 42 \\
Warsaw area & \\
\hline Parity, (\%) & 44 \\
primipara & 56 \\
\hline multipara & 15 \\
\hline Smoking during pregnancy, (\%) & \\
\hline
\end{tabular}

gowaniu żywienia bogatego w kwas foliowy oraz codziennego przyjmowania tego składnika w dawce 400 $\mu$ g przez wszystkie kobiety, które mogą zajść w ciążę. Suplementacja taka powinna być kontynuowana przynajmniej przez pierwsze 12 tygodni ciąży (12). Przyjmowanie kwasu foliowego w okresie przedkoncepcyjnym wynika z faktu, że wady cewy nerwowej, na skutek jej niepełnego zamknięcia powstają już na przełomie 3. i 4. tygodnia życia płodowego, zwykle zanim kobieta dowiaduje się, że jest w ciąży. Rozpoczęcie suplementacji dopiero od momentu stwierdzenia ciąży przez ginekologa jest zazwyczaj zbyt późne $(9,13)$. Programem objęte są wszystkie kobiety w wieku rozrodczym, ponieważ 95\% przypadków wad cewy nerwowej zdarza się po raz pierwszy $(5,6)$. Jednakże w ślad za nowymi wynikami badań zmienia się stanowisko ekspertów, dotyczące momentu, od którego należy zażywać kwas foliowy. Zgodnie z pierwotnym założeniem należało go zażywać przynajmniej 4 tygodnie przed zajściem w ciążę (12), w 2014 r. Polskie Towarzystwo Ginekologiczne rekomendowało już 6 tygodni (14), a w świetle najnowszych zaleceń tego Towarzystwa (2017 r.) suplementację należy rozpocząć, co najmniej 12 tygodni przed zajściem w ciążę (15).

\section{CEL PRACY}

Celem badania była ocena częstości i prawidłowości stosowania preparatów kwasu foliowego przed zajściem w ciążę oraz w okresie ciąży, przez kobiety $\mathrm{z}$ regionu warszawskiego.

\section{MATERIAŁ I METODY}

Badanie przeprowadzono wśród 100 kobiet ciężarnych, rodzących w Klinice Położnictwa, Chorób Kobiecych i Ginekologii Onkologicznej II Wydziału Lekarskiego, Warszawskiego Uniwersytetu Medycznego, w latach 2014-2015. Informacje dotyczące przyjmowania kwasu foliowego oraz dane socjologiczne zebrano metodą bezpośredniego wywiadu z pacjentkami, przeprowadzanego zawsze przez tego samego dietetyka. Charakterystykę pacjentek przedstawia tabela I.

Związek wybranych czynników (wiek kobiet, ich wykształcenie, miejsce zamieszkania, liczba ciąż, palenie tytoniu podczas ciąży) ze stosowaniem kwasu foliowego zbadano przy pomocy testu $\mathrm{chi}^{2}$. Za kryterium istotności przyjęto $p<0,05$. Analizę wykonano w programie Stata v. 14.1 


\section{RESULTS}

\section{Folic acid supplementation before conception}

Folic acid supplementation before pregnancy was reported by $42 \%$ of the subjects, and was more common among non-smokers and primiparas as compared to smokers and multiparas (Table 2).

The reported time of folic acid supplementation ranged from 1 week to 3 years before conception. Out of the $42 \%$ of women, the highest number of subjects $(23 \%)$ used folic acid in accordance with the recommendations, i.e. for at least 3 months before conception, $8 \%$ for 1-3 months, and the remaining $11 \%$ for under one month. Almost all of these women (41\%) used single preparations of folic acid and only 1 subject used a complex vitamin/mineral preparation.

\section{WYNIKI}

\section{Stosowanie kwasu foliowego w okresie przed- koncepcyjnym}

Kwas foliowy przed zajściem w ciążę przyjmowało $42 \%$ badanych pacjentek. Bardziej powszechne było to wśród kobiet $\mathrm{w}$ ciąży pierwszej, a także niepalących w okresie ciąży, niż kobiet w ciąży kolejnej i kobiet palących tytoń (Tab. II).

Deklarowany przez pacjentki okres suplementacji wynosił od 1 tygodnia do 3 lat przed zajściem w ciążę. Najwięcej kobiet (23\%) stosowało kwas foliowy prawidłowo, czyli co najmniej 3 miesiące przed zajściem w ciążę, $8 \%$ w okresie 1-3 miesięcy, a pozostałe $11 \%$ krócej, niż miesiąc. Niemal wszystkie pacjentki (41\%) przyjmowały pojedyncze preparaty kwasu foliowego, a tylko jedna z nich złożony preparat witaminowo-mineralny.

Table 2. Characteristics of the women who supplemented folic acid before conception

Tabela 2. Charakterystyka kobiet, które przyjmowały kwas foliowy przed zajściem w ciążę

\begin{tabular}{|l|c|c|}
\hline & $\begin{array}{c}\text { Number of women who supplemented } \\
\text { folic acid, percentage } \\
\text { n, (\%) }\end{array}$ & $p$-value \\
\hline $\begin{array}{l}\text { Age: } \\
\leq 30 \text { years }\end{array}$ & $19,(40)$ & 0.594 \\
$>30$ years & $23,(45)$ & 0.218 \\
\hline $\begin{array}{l}\text { Education: } \\
\text { higher }\end{array}$ & $31,(46)$ & \\
other & $11,(33)$ & 0.501 \\
\hline Place of residence: & $26,(45)$ & \\
Warsaw city & $16,(38)$ & 0.028 \\
Warsaw area & $23,(55)$ & \\
\hline Parity: & $19,(33)$ & 0.040 \\
primipara & & \\
multipara & $4,(21)$ & \\
\hline Smoking during pregnancy: & $38,(47)$ & \\
yes & & \\
no & & \\
\hline
\end{tabular}

\section{Folic acid supplementation during pregnancy}

A total of $83 \%$ of the respondents reported folic acid supplementation during pregnancy. After taking into account the women who used folic acid supplementation before conception, $41 \%$ of the patients started to supplement folic acid during pregnancy. Almost all women (77\% of the study population) reported folic acid supplementation in the form of a complex vitamin/mineral preparation for pregnant women, and $7 \%$ additionally used a single preparation of folic acid, which might increase the risk of excessive supply. Only a single preparation of folic acid was used in pregnancy by $6 \%$ of the investigated women.

Out of the women who used folic acid in pregnancy, $71 \%$ started supplementation at 5-6 weeks of gestation

\section{Stosowanie kwasu foliowego w okresie ciąży}

Suplementację diety kwasem foliowym w okresie ciąży stosowało $83 \%$ kobiet. Po uwzględnieniu tych pacjentek, które realizowały to jeszcze przed zajściem w ciążę, rozpoczęcie suplementacji dotyczyło $41 \%$ pacjentek. Prawie wszystkie kobiety $(77 \%$ badanej grupy) zadeklarowały, że po rozpoznaniu ciąży kwas foliowy przyjmowały $\mathrm{w}$ formie preparatu witaminowo -mineralnego, przeznaczonego dla kobiet ciężarnych, a 7\% kobiet łączyło go dodatkowo z pojedynczym preparatem kwasu foliowego, co mogło zwiększać ryzyko nadmiernego pobrania. Wyłącznie pojedynczy kwas foliowy stosowało w okresie ciąży $6 \%$ badanych kobiet. 
or later. The remaining women initiated folic acid supplementation slightly earlier, i.e. at 3-4 weeks of gestation. All women continued to supplement folic acid until pregnancy completion.

\section{DISCUSSION}

Demands for folate are elevated in pregnancy and increase up to $600 \mu \mathrm{g} /$ day (4). Higher doses of the folic acid (even $5000 \mu \mathrm{g}$ ) are being recommended as an important adjunctive strategy for perinatal unipolar depression that may be particularly effective in women with low serum folate levels (16).

Despite the fact that an increase in folate consumption has been advocated and recommended for years, it remains relatively small and unchanged over time. In 2004, pregnant women in Poland consumed on average $181 \mu \mathrm{g}$ of folic acid a day (17). An almost identical consumption (160-180 $\mu \mathrm{g})$ was reported between 2009-2013 (18, 19), and a slightly higher consumption $(254 \mu \mathrm{g})$ was reported in 2018 (20).

In light of the confirmed relationship between folate deficiency and neural tube defects, numerous countries introduced mandatory fortification with folic acid of certain foods, chief among them flour (67 countries globally, 2012) (9). Canada and the USA were the first to do this and have been fortifying flour with folic acid $(150 \mu \mathrm{g} / 100 \mathrm{~g})$ for over 20 years, which increases folic acid consumption by $100-150 \mu \mathrm{g} / \mathrm{day}$ (21). In the European Union, food fortification is not mandatory, but producers may fortify foods on their own account. According to the 2009 report by Sicińska and Pelc, 166 fortified products, predominantly cereal (40\%), followed by juices, nectars, and drinks, were available in the city of Warsaw (22).

Mandatory fortification of foods is undoubtedly the most effective preventive measure for NTDs. According to some data, the rates of spina bifida - one of the most common NTDs - between 1985-2010 in such countries were significantly lower as compared to countries without mandatory fortification of foods with folic acid (33.9/100 000 live births and 48.4/100 000 live births, respectively) (9). In Europe, according to the European Surveillance of Congenital Anomalies (EUROCAT), the number of spina bifida cases between 1991-2011 was 46.3/100 000 births and of all NTDs cases was 91.1/100 000 births. The incidence of NTDs in the Wielkopolska region, Poland, was $92.5 / 100000$ births (23). The abovementioned authors emphasize that, due to lack of mandatory fortification, the situation in Europe in 2011 showed no improvement as compared to 1991 , despite two decades of recommendations to supplement folic acid among reproductive-age women.
Spośród tych pacjentek, które przyjmowały kwas foliowy będąc w ciąży, 71\% rozpoczęło jego przyjmowanie dopiero od 5-6 tygodnia ciąży lub później. Pozostałe pacjentki twierdziły, że suplementację zaczęły nieco wcześniej tj. od 3-4 tygodnia ciąży. Wszystkie kobiety kontynuowały przyjmowanie kwasu foliowego do zakończenia ciąży.

\section{DYSKUSJA}

Zapotrzebowanie kobiet ciężarnych na kwas foliowy jest podwyższone i wynosi $600 \mu \mathrm{g} / \mathrm{dzień} \mathrm{(4).} \mathrm{Wyż-}$ sze dawki kwasu foliowego (nawet $5000 \mu \mathrm{g}$ ) mogą być niezbędne, w przypadku kobiet ciężarnych z jednobiegunową depresją, szczególnie w sytuacji niskiego stężenia kwasu foliowego w surowicy krwi (16). Pomimo wieloletnich zaleceń zwiększenia jego spożycia przez kobiety ciężarne wciąż jest ono niewielkie i niezmienne w czasie. W 2004 r. kobiety ciężarne w Polsce spożywały z dietą średnio $181 \mu \mathrm{g}$ kwasu foliowego dziennie (17), takie same ilości (160-180 $\mu \mathrm{g})$ stwierdzano w latach 2012-2013 $(18,19)$ i niewiele różnią się dane $\mathrm{z}$ roku 2018 - $254 \mu \mathrm{g}(20)$.

Biorąc pod uwagę związek pomiędzy niedoborem kwasu foliowego a wadami cewy nerwowej płodu w wielu krajach podjęto decyzję o obligatoryjnym wzbogacaniu żywności w ten składnik. Najbardziej popularne stało się wzbogacanie mąki, które w 2012 r. realizowało 67 krajów na świecie (9). Jako pierwsze wprowadziły to Stany Zjednoczone i Kanada, gdzie od ponad 20 lat dodaje się do mąki kwas foliowy w dawce $150 \mu \mathrm{g} / 100 \mathrm{~g}$, co zwiększa jego spożycie z dietą o 100-150 $\mu \mathrm{g} / \mathrm{dzień} \mathrm{(21).} \mathrm{W} \mathrm{Unii} \mathrm{Europejskiej} \mathrm{nie} \mathrm{ma}$ obowiązku wzbogacania produktów w kwas foliowy, ale istnieje możliwość jego dobrowolnego dodatku przez producentów. $Z$ oszacowania przeprowadzonego w 2009 r. przez Sicińska i Pelc wynika, że na rynku warszawskim znajdowało się 166 takich produktów, z czego najwięcej stanowiły płatki śniadaniowe ( $40 \%$ ogółu wzbogacanych produktów), a następnie soki, nektary i napoje (22).

Obowiązkowe wzbogacanie żywności przynosi najlepsze efekty profilaktyki wad cewy nerwowej. Statystyki podają, że w takich krajach ilość rozszczepów kręgosłupa (jednej z najczęstszych wad cewy nerwowej) w latach 1985-2010 była znacznie mniejsza (33,9/100 000 żywych urodzeń), niż w krajach bez obowiązkowego wzbogacania $(48,4 / 100000$ żywych urodzeń) (9). W Europie, według bazy EUROCAT (lata 1991 - 2011) liczba rozszczepów kręgosłupa wynosiła 46,3/100 000 urodzeń, a wszystkich wad cewy nerwowej - 91,1/100 000 urodzeń (23). Zawarte w ww. bazie dane z Polski (z regionu Wielkopolski) wskazują, że częstość wad cewy nerwowej u noworodków wynosiła 92,5/100 000 urodzeń. Autorzy tego opraco- 
The realization of the NDTs prevention programs remains unsatisfactory due to a small percentage of women who follow the recommendations about folic acid supplementation (23). Between 2005 and 2007, local studies found that only $27.5 \%$ of the women from Cracow (24), and $31 \%$ of the women from the Warsaw region (25) supplemented folic acid before conception. In the subsequent years, those percentages in the local populations ranged from $36 \%$ to $55 \%$ (2628). A national study from 2017 revealed that $41 \%$ of the women declared folic acid supplementation before conception (29), which was similar to the results of the national study from $2013-37 \%$ (30). The result of the present study (42\%) indicates a stable trend as far as pre-pregnancy folic acid supplementation is concerned. A relatively high number of such women has been noted in the USA (51-53\%), despite increased folic acid consumption due to mandatory flour fortification (31, 32 ), whereas in the UK, France and Japan the rates are significantly lower $(31 \%, 26 \%$ and $21 \%$, respectively) (33-35).

A study by Pietrzykowska-Kuncman et al., conducted among female physicians who started to work with NTD children, is an example of how attitudes towards folic acid supplementation may evolve under certain circumstances. These authors demonstrated that all physicians who conceived after they had started the work in question supplemented folic acid before conception, as compared to $38 \%$ of the physicians whose previous pregnancy had occurred before working with NTD children (36).

In our study, the percentage of women who supplemented folic acid during pregnancy doubled $(83 \%)$, and was consistent with the results of other authors $(86-94 \%)(20,25,28,29)$. Also, we confirmed the previously reported practice of late folic acid supplementation among pregnant women. The study by Jarosz and Wierzejska, from 2005-2007, demonstrated that $66 \%$ of women supplementing folic acid in the first trimester of pregnancy started no sooner that 4-5 weeks of gestation, or even later (25). According to Atta et al., neural tube closure occurs on day 28 of pregnancy and since that day forward the role of folic acid is no longer preventive (9).

\section{CONCLUSION}

Pre-pregnancy folic acid supplementation was reported by under half of our study population. During pregnancy, the percentage of those women was significantly higher and doubled. However, despite the fact that most of the subjects initiated folic acid supplementation immediately after the diagnosis of pregnancy, the supplementation was started too late as far as NTD prevention is concerned. Since very early wania wyraźnie podkreślają, że w Europie, na skutek braku obowiązku wzbogacania żywności, sytuacja pod względem częstości tego powikłania w roku 2011 nie była korzystniejsza, niż w roku 1991, pomimo wieloletnich rekomendacji stosowania kwasu foliowego przez kobiety w wieku rozrodczym.

Realizacja profilaktyki wad cewy nerwowej nie jest zadowalająca, ponieważ mały odsetek kobiet prawidłowo przyjmuje kwas foliowy (23). W Polsce, w latach 2005-2007 w badaniach lokalnych na grupie kobiet ciężarnych z Krakowa stwierdzono, że przed zajściem w ciążę przyjmowało go tylko $27,5 \%$ kobiet (24), a w grupie kobiet $\mathrm{z}$ regionu warszawskiego $31 \%$ (25). W kolejnych latach w lokalnych populacjach odsetek ten wynosił od 36 do 55\% (26-28). Badanie na grupie ogólnopolskiej, przeprowadzone w 2017 r. wykazało, że przyjmowanie kwasu foliowego przed zajściem w ciążę deklarowało 41\% kobiet (29), co było zbliżone do wyniku takiego badania z roku 2013 (37\%) (30). Uzyskany w naszym badaniu wynik (42\% kobiet) wskazuje zatem na dość stałą sytuację. Stosunkowo duży odsetek takich kobiet notuje się w USA (51-53\%), pomimo zwiększonego spożycia kwasu foliowego z dietą, na skutek obowiązkowego wzbogacania mąki $(31,32)$, natomiast w Anglii dotyczy to tylko 31\% kobiet (33), we Francji 26\% (34), a w Japonii odsetek ten jest jeszcze mniejszy (21\%) (35).

Przykładem, jak bardzo może zmienić się podejście kobiet do wagi tego zagadnienia są wyniki badania Pietrzykowskiej-Kuncman i wsp., prowadzonego wśród lekarek, które zaczęły pracę zawodową z dziećmi z wadą cewy nerwowej (36). Wykazało ono, że wszystkie lekarki, które zaszły w ciążę po rozpoczęciu tej pracy zażywały kwas foliowy w okresie przedkoncepcyjnym, w stosunku do 38\% lekarek, których poprzednia ciąża miała miejsce przed podjęciem zatrudnienia z chorymi dziećmi.

W okresie ciąży odsetek kobiet przyjmujących kwas foliowy w naszym badaniu wzrósł dwukrotnie (83\%) i był zbliżony do wyników badań innych autorów $(86-94 \%)(20,25,28,29)$. Badanie potwierdza także stwierdzaną już wcześniej praktykę późnego sięgania po kwas foliowy. Badanie Jarosza i Wierzejskiej z lat 2005-2007 wykazało, że 66\% kobiet stosujących kwas foliowy w I trymestrze ciąży rozpoczęło suplementację dopiero od 4-5 tygodnia ciąży, a nawet później (25). Jak podaje Atta i wsp. cewa nerwowa płodu, jako zawiązek centralnego układu nerwowego zamyka się 28 dnia ciąży i kwas foliowy odgrywa profilaktyczną rolę jedynie do tego okresu (9).

\section{WNIOSKI}

Stosowanie kwasu foliowego przed zajściem w ciążę stwierdzono u mniej niż połowy kobiet. W okresie 
detection of pregnancy by the women is understandably problematic, only pre-pregnancy supplementation with folic acid may be effective.

\section{REFERENCES}

1. Naderi N., House J.D.: Recent Developments in Folate Nutrition. Adv Food Nutr Res 2018;83:195213.

2. Hwang S.Y., Kang Y.J., Sung B., et al.: Folic acid is necessary for proliferation and differentiation of C2C12 myoblasts. J Cell Physiol 2018;233(2):736747.

3. Cieślik E., Kościej A.: Folic acid - occurrence and significance. Probl Hig Epidemiol 2012;93(1):1-7 (in Polish).

4. Jarosz M., Stoś K., Przygoda B., i in..: Witaminy. W: Jarosz M, red. Normy żywienia dla populacji Polski. Warszawa, IŻŻ, 2017, 166-169.

5. Prevention of neural tube defects: results of the Medical Research Council Vitamin Study. MRC Vitamin Study Research Group. Lancet 1991;338(8760):131-137.

6. Czeizel A.E., Dudás I.: Prevention of the first occurrence of neural-tube defects by periconceptional vitamin supplementation. N Engl J Med 1992;327(26):1832-1835.

7. Berry R.J., Li Z., Erickson J.D., Li S., Moore C.A., et al.: Prevention of neural-tube defects with folic acid in China. China-U.S. Collaborative Project for Neural Tube Defect Prevention. N Engl J Med 1999;341(20):1485-1490.

8. De-Regil L.M., Peña-Rosas J.P., FernándezGaxiola A.C., et al.:Effects and safety of periconceptional oral folate supplementation for preventing birth defects. Cochrane Database Syst Rev 2015;(12). doi: 10.1002/14651858. CD007950.

9. Atta C.A.M., Fiest K.M., Frolkis A.D., et al.: Global birth prevalence of spina bifida by folic acid fortification status: A systematic review and meta-analysis. Am J Public Health 2016;106(1). doi: 10.2105/AJPH.2015.302902.

10. Copp A.J., Adzick N.S., Chitty L.S., et al.: Spina bifida. Nat Rev Dis Primers 2015; 30;1:15007.

11. Recommendations for the use of folic acid to reduce the number of cases of spina bifida and other neural tube defects. MMWR Recomm Rep Morb Mortal Wkly Rep Recomm Rep Cent Dis Control 1992; 41:1-7, indexed in Pubmed: 1522835.

12. Brzeziński Z. Strategie zapobiegawcze. W: Brzeziński Z, red. Zapobieganie wadom cewy nerwowej. Warszawa, IMiDz, 1998, 81.

13. Eichholzer M., Tönz O., Zimmermann R.: Folic acid: a public-health challenge. Lancet 2006;367:1352-1361.

14. Karowicz-Bilińska A., Nowak-Markwitz E., Opala T., et al. Rekomendacje Polskiego ciąży odsetek kobiet był znacznie wyższy, ale pomimo tego, że większość z nich rozpoczęła suplementację z chwilą rozpoznania ciąży to $\mathrm{w}$ profilaktyce wad cewy nerwowej płodu było to zbyt późne. W związku z oczywistym problemem rozpoznania przez kobiety bardzo wczesnej ciąży efektywne może być tylko przyjmowanie tego składnika w okresie przedkoncepcyjnym.

Towarzystwa Ginekologicznego w zakresie stosowania witamin i mikroelementów u kobiet planujących ciążęe, ciężarnych i karmiących. Ginekol Pol 2014;85:395-399.

15. Bomba-Opoń D., Hirnle ., Kalinka J, et al..: Folate supplementation during the preconception period, pregnancy and puerperium. Polish Society of Gynecologists and Obstetricians Guidelines. Ginekol Pol 2017;88(11):633-636. doi:10.5603/ GP.a2017.0113.

16. Deligiannidis K.M., Freeman M.P. Complementary and alternative medicine therapies for perinatal depression. Best Pract Res Clin Obstet Gynaecol 2014;28(1):85-95.

17. Weker H., Strucińska M., Więch M., i in..: Ocena sposobu żywienia kobiet $\mathrm{w}$ okresie ciąży - suplementacja preparatami witaminowomineralnymi uzasadniona czy nie? Przegl Lek 2004;61(7):769-775.

18. Bojar I., Owoc A., Humeniuk E., et al. : Inappropriate consumption of vitamins and minerals by pregnant women in Poland. Ann Agric Environ Med 2012;19: 263-266.

19. Myszkowska-Ryciak J., Gurtatowska A., Harton A., et al.: Nutritional knowledge and selected aspects of the diet of pregnant women. Probl Hig Epidemiol 2013;94(3): 600-604 (in Polish).

20. Kocyłowski R., Lewicka I., Grzesiak M., et al.: Assessment of dietary intake and mineral status in pregnant women. Arch Gynecol Obstet 2018;297(6):1433-1440. doi: 10.1007/s00404-0184744-2.

21. Berry R.J., Bailey L., Mulinare J., et al.: Fortification of flour with folic acid. Food Nutr Bull 2010;31(1 Suppl):22-35.

22. Sicińska E., Pelc A.: Fortified food products as a potential source of folic acid in human nutrition. Rocz Panstw Zakl Hig 2011;62(2):209-214 (in Polish).

23. Khoshnood B., Loane M., de Walle H., et al.: Long term trends in prevalence of neural tube defects in Europe: population based study. BMJ 2015;351. doi:10.1136/bmj.h5949.

24. Gacek M.: Some health behaviours and selected health status coefficients in a group of pregnant women. Probl Hig Epidemiol 2010;91(1):48-53 (in Polish). 
25. Jarosz M., Wierzejska R.: Suplementacja kwasem foliowym diet kobiet ciężarnych. Żyw Człow Metab 2007;34(5):1499-1508 (in Polish).

26. Bagłaj M., Wojtyłko A.: Folic acid supplementation as prophylaxis of neural tube defect in the Lower Silesia region: fact or myth? Med Wieku Rozwoj 2011;(4) (in Polish).

27. Hamułka J., Wawrzyniak A, Pawłowska R.: Assessment of vitamins and minerals intake with supplements in pregnant women. Rocz Panstw Zakl Hig 2010;61(3):269-275 (in Polish).

28. Kurzawińska G., Magiełda J., Romała A., et al.: Demographic factors determining folic acid supplementation in pregnant and childbearing age women. Ginekol Pol 2018;89(4):211-216. doi: 10.5603/GP.a2018.0036.

29. Raport z badania „Zachowania zdrowotne kobiet w ciąży”. ProVision Solution, Warszawa 2017.

30. Raport z badania „Zachowania zdrowotne kobiet w ciąży". Instytut Medycyny Wsi im. Witolda Chodźki, Lublin 2013.

31. Carmichael S.L., Shaw G.M., Yang W., et al.: Correlates of intake of folic acid-containing supplements among pregnant women. Am J Obstet Gynecol 2006;194(1):203-210.

32. Hoyo C., Murtha A.P., Schildkraut J.M., et al.: Folic acid supplementation before and during pregnancy in the Newborn Epigenetics Study (NEST). BMC Public Health 2011;11(1):46. doi: 10.1186/14712458-11-46.
33. Bestwick J.P., Huttly W.J., Morris J.K., et al.: Prevention of neural tube defects: a cross-sectional study of the uptake of folic acid supplementation in nearly half a million women. PLoS One 2014;9(2):e89354.

34. Camier A., Kadawathagedara M., Lioret S., et al.: Social inequalities in prenatal folic acid supplementation: Results from the ELFE Cohort. Nutrients 2019;11(5). doi: 10.3390/nu11051108.

35. Yamamoto S., Wada Y.: Awareness, use and information sources of folic acid supplementation to prevent neural tube defects in pregnant Japanese women. Public Health Nutr 2018;21(4):732-739. doi: 10.1017/S1368980017003172.

36. Pietrzykowska-Kuncman M., Zasina-Olaszek D., Łukasz K., et al. Intake of folic acid by Polish women with higher education - a survey research: can we do more? Ginekol Pol 2017;88(8):428-433. doi: 10.5603/ GP.a2017.0079.

Received: 31.01.2020

Accepted for publication: 24.04.2020

Otrzymano: $31.01 .2020 \mathrm{r}$.

Zaakceptowano do publikacji: $24.04 .2020 \mathrm{r}$.

\section{Address for correspondence:}

Adres do korespondencji:

Regina Wierzejska, National Institute of Public Health

- National Institute of Hygiene

Powsińska St. 61/63, 02-903 Warsaw, Poland

e-mail: rwierzejska@pzh.gov.pl 